\title{
Hubungan Pemberian Terapi Antipsikotik terhadap Kejadian Efek Samping Sindrom Ekstrapiramidal pada Pasien Rawat Jalan di Salah Satu Rumah Sakit di Bantul, Yogyakarta
}

\section{Haafizah Dania ${ }^{1,2}$, Imaniar N. Faridah ${ }^{1}$, Khansa F. Rahmah ${ }^{1}$, Rizky Abdulah ${ }^{2,4}$,} Melisa I. Barliana, ${ }^{3,4}$, Dyah A. Perwitasari' ${ }^{\prime}$

${ }^{1}$ Fakultas Farmasi, Universitas Ahmad Dahlan, Yogyakarta, Indonesia, ${ }^{2}$ Departemen Farmakologi dan Farmasi Klinik, Fakultas Farmasi, Universitas Padjajaran, Sumedang, Indonesia, ${ }^{3}$ Departemen Biologi Farmasi, Fakultas Farmasi, Universitas Padjajaran, Sumedang, Indonesia, ${ }^{4}$ Pusat Unggulan Riset Inovasi Pelayanan Kefarmasian, Universitas Padjajaran, Sumedang, Indonesia

\begin{abstract}
Abstrak
Skizofrenia merupakan penyakit gangguan jiwa terbanyak yang memiliki prognosis yang buruk, dengan remisi total hanya dialami oleh sekitar $20 \%$ penderitanya, sedangkan sisanya akan mengalami berbagai tingkat kesulitan dan kemunduran secara klinis dan sosial. Antipsikotik merupakan terapi utama pada skizofrenia, namun pemberian terapi ini terkadang dapat menimbulkan efek samping, salah satunya adalah sindrom ekstrapiramidal yang dapat menyebabkan pasien enggan untuk minum obat secara rutin, akibatnya frekuensi kekambuhan menjadi meningkat. Penelitian ini bertujuan untuk menganalisis hubungan terapi antipsikotik terhadap kejadian sindrom ekstrapiramidal pada pasien skizofrenia rawat jalan di salah satu rumah sakit di wilayah Bantul, Yogyakarta. Penelitian ini merupakan penelitian observasional dengan desain penelitian cross-sectional dengan pengambilan data secara retrospektif menggunakan data rekam medis pasien skizofrenia yang menjalani rawat jalan di salah satu rumah sakit di wilayah Bantul, Yogyakarta pada periode Januari-Desember 2017. Jumlah sampel dalam penelitian ini adalah 100 orang pasien dengan kriteria inklusi yaitu pasien skizofrenia dengan usia $>15$ tahun dan mendapatkan terapi antipsikotik selama minimal 4 minggu, sedangkan kriteria ekslusi yaitu pasien yang mendapatkan terapi metoklopramid dan mempunyao riwayat sindrom ekstrapiramidal sebelumnya. Pengambilan sampel dilakukan menggunakan teknik purposive sampling. Analisis data menggunakan uji Chi-Square dengan menggunakan program SPSS versi 16.0. Diperoleh bahwa sebagian besar pasien mendapat risperidon sebesar 27\%, risperidon+klozapin $17 \%$, dan haloperidol+klozapin $10 \%$. Pada pasien yang memperoleh terapi antipsikotik tunggal, sebanyak 5 orang mengalami efek samping sindrom ekstrapiramidal, sedangkan pada pasien yang memperoleh terapi antipsikotik kombinasi, 7 orang mengalami efek samping sindrom ekstrapiramidal. Hasil analisis uji Chi-Square menunjukkan bahwa tidak terdapat hubungan baik itu antara penggunaan terapi antipsikotik (tunggal maupun kombinasi) $(\mathrm{p}=1,000)$, antara terapi antipsikotik tunggal (tipikal maupun atipikal) $(\mathrm{p}=0,467)$, dan antara terapi antıpsikotik kombinasi (atipikal-atipikal, tipikal-tipikal, dan tipikal-atipikal) $(\mathrm{p}=0,269)$, dengan kejadian efek samping sindrom ekstrapiramidal.
\end{abstract}

Kata kunci: Antipsikotik, sindrom ekstrapiramidal, skizofrenia

\section{Relationship between the Use of Antipsychotic and Incident of Extrapyramidal Syndrome on Schizophrenic Outpatients at One of Hospitals in Bantul, Yogyakarta}

\begin{abstract}
Schizophrenia is the most kind of psychiatric diseases which has bad prognosis with total remision only around $20 \%$, otherwise social and clinical difficulties will be faced by the rest. Antipsychotic is a first line therapy for schizophrenic patients, however it has some side effects such as extrapyramidal syndrome that make people reluctant to take the medication regularly. Furthermore, the number of recurrence is increasing. The aim of this study was to analyze the relationship between the use of antipsychotic and the incident of extrapyramidal syndrome in outpatient schizophrenia in one of hospitals in Bantul region, Yogyakarta. This study was observational study, using cross-sectional design. Data was taken retrospectively using patients' medical records who were outpatients in one of hospitals in Bantul region, Yogyakarta, in the period of January-December 2017. The sample of this research was 100 patients. The inclusion criteria was schizophrenic patients aged $>15$ years old who took an antipsychotic therapy for a minimum of 4 weeks, while the exclusion criteria was patients who took metoclopramide as a therapy and had a history of extrapyramidal syndrome previously. Purposive sampling was used as a technique for sampling. Data analysis was conducted using Chi-Square by SPSS ver. 16.0. Results of this study is most patients took risperidon e (27\%), risperidone+clozapine $17 \%$, and haloperidol+clozapine $10 \%$. The incident of extrapyramidal syndrome happened in 5 patients who took single antipsychotic and in 7 patients who took combination antipsychotic. However, the Chi-Square analysis showed that there was no relationship between the use of antipsychotic (single or combination) and the incident of extrapyramidal syndrome ( $\mathrm{p}$-value $=1.000)$. Likewise, there was no relationship between the use of single (both typical and atypical) antipsychotic therapy ( $p$-value $=0.467$ ), also no relationship between the use of combination (atypical-atypical typical-typical and atypical) antipsychotic therapy $(p$-value $=0.269)$ and the incident of extrapyramidal syndrome side-effects.
\end{abstract}

Keywords: Antipsychotics, extrapyramidal syndrome, schizophrenia

Korespondensi: Haafizah Dania, M.Sc., Apt., Fakultas Farmasi, Universitas Ahmad Dahlan, Yogyakarta, Daerah Istimewa Yogyakarta 55164, Indonesia,email: fizadan.djogja@gmail.com

Naskah diterima: 22 Januari 2019, Diterima untuk diterbitkan: 12 Februari 2019, Diterbitkan: 1 Maret 2019 


\section{Pendahuluan}

Data Riskesdas tahun 2013 menunjukkan bahwa satu hingga dua orang dari 1000 orang mengalami gangguan jiwa berat. Prevalensi psikosis tertinggi di Indonesia berdasarkan survei kesehatan terdapat di Provinsi Daerah Istimewa Yogyakarta (DIY) dan Aceh, yakni sebesar $2.7 \%$ per mil. Prevalensi gangguan jiwa berat tertinggi di Provinsi DIY terdapat di Kabupaten Kulon Progo dengan nilai 4,67 per mil, disusul oleh Bantul, Gunung Kidul, Sleman, dan Kota Yogyakarta. ${ }^{1}$

Manajemen terapi yang paling efektif pada pasien skizofrenia adalah terapi antipsikotik. Golongan antipsikotik dibagi ke dalam dua jenis, yakni antipsikotik generasi pertama dan generasi kedua. Antipsikotik generasi pertama (tipikal) mempunyai keterbatasan berupa efek samping sindrom ekstrapiramidal (EPS) yang mengganggu aktivitas pasien sehingga berujung pada ketidakpatuhan pasien dalam melanjutkan pengobatan, sebagai akibatnya frekuensi kekambuhan menjadi meningkat. ${ }^{2}$ Kejadian EPS ini dapat muncul sejak awal pemberian antipsikotik, hal ini bergantung dari besarnya dosis yang diberikan. ${ }^{3}$ Hasil penelitian yang dilakukan oleh Jesic et al. (2012) menyatakan bahwa efek samping EPS umumnya muncul pada pasien skizofrenia setelah penggunaan terapi selama 4 minggu. ${ }^{4}$ Antipsikotik generasi kedua (atipikal) sedikit atau bahkan tidak memiliki efek samping EPS pada dosis rendah. ${ }^{5}$ Antipsikotik atipikal ini berhubungan dengan risiko peningkatan berat badan, gangguan kardiovaskular, dan diabetes melitus yang lebih besar dan risiko terjadinya gejala ekstrapiramidal yang lebih rendah bila dibandingkan dengan antipsikotik tipikal.,56 Antipsikotik atipikal dengan gejala ekstrapiramidal yang lebih rendah antara lain aripiprazol, quetiapin, dan klozapin. ${ }^{5}$

Pemberian antipsikotik dapat menyebabkan respon yang buruk dan efek samping seperti gejala ekstrapiramidal, ${ }^{7,8}$ sindrom metabolik, dan juga kenaikan berat badan yang akan memperburuk kondisi pasien. ${ }^{9,10}$ Oleh karena itu, praktisi sering kali melakukan pergantian terapi ${ }^{11,12}$ yang tidak efektif yaitu berdasarkan trial dan error ${ }^{13}$ sehingga pasien mengalami banyak kejadian yang tidak diinginkan, seperti efek rebound dan kekambuhan. ${ }^{14,15}$

Kejadian efek samping terbanyak yang dialami pasien skizofrenia pada penelitian Julaeha et al. (2016) adalah efek samping EPS, kemudian disusul dengan hipotensi dan kenaikan enzim SGPT/SGOT. Antipsikotik potensi rendah menyebabkan sebanyak 2,3$10 \%$ pasien mengalami EPS, sedangkan untuk antipsikotik potensi tinggi menyebabkan 64\% pasien mengalami efek samping EPS.

Hasil penelitian oleh Jarut et al. (2013) di Rumah Sakit Prof. Dr. V. L. Ratumbuysang Manado menunjukkan bahwa penggunaan antipsikotik tunggal paling banyak adalah risperidon yakni sejumlah 30 pasien $(21,1 \%)$ dan antipsikotik kombinasi paling banyak adalah haloperidol-klorpromazin sejumlah 33 pasien (23,2\%). Penggunaan antipsikotik terbanyak berdasarkan kategori pengobatan adalah antipsikotik tipikal, dan antipsikotik ini lebih banyak digunakan bila dibandingkan antipsikotik lainnya, yaitu sebesar 59 pasien $(41,5 \%)$ menggunakan terapi antipsikotik tipikal ini. Antipsikotik tipikal diketahui hanya berefek pada gejala positif saja, selain itu antipsikotik tipikal juga memiliki efek yang tinggi dalam menghambat reseptor dopamin 2 (D2) sehingga dapat menyebabkan efek samping EPS yang lebih kuat dibandingkan antipsikotik lainnya. ${ }^{16}$

Rumah sakit di wilayah Bantul, Yogyakarta (selanjutnya disebut RS X) dipilih sebagai tempat penelitian kerena Bantul merupakan daerah dengan prevalensi skizofrenia tertinggi kedua di Provinsi DIY setelah Kulonprogo, sehingga diharapkan peneliti mendapatkan kemudahan dalam memperoleh jumlah pasien skizofrenia. Mengingat pentingnya pemilihan obat antipsikotik yang digunakan pada pasien 
skizofrenia untuk mengurangi gejala positif dan negatif, juga dengan mempertimbangkan risiko munculnya efek samping pemberian antipsikotik, salah satunya EPS, maka perlu dilakukan suatu penelitian untuk menganalisis hubungan penggunaan antipsikotik dengan kejadian EPS pada pasien skizofrenia.

\section{Metode}

Penelitian ini telah memperoleh persetujuan laik etik Komite Etik Penelitian Universitas Ahmad Dahlan dengan nomor 011804070.

Desain penelitian

Penelitian ini adalah penelitian observasional analitik dengan pendekatan cross-sectional Pengambilan data dilakukan secara retrospektif dengan menggunakan data rekam medik pasien skizofrenia rawat jalan Rumah Sakit X di wilayah Bantul, Yogyakarta.

Tempat dan waktu penelitian

Penelitian ini dilakukan di Rumah Sakit X wilayah Bantul, Yogyakarta. Pengambilan data dilakukan pada bulan September-November 2018. Data rekam medik yang diambil adalah data pada periode Januari-Desember 2017.

Populasi dan sampel

Populasi pada penelitian ini adalah rekam medis pasien skizofrenia rawat jalan di Rumah Sakit X di wilayah Bantul, Yogyakarta bulan Januari sampai dengan Desember tahun 2017. Kriteria inklusi yaitu pasien dengan diagnosis skizofrenia, usia $>15$ tahun, mendapat terapi antipsikotik minimal penggunaan 4 minggu, sedangkan kriteria eksklusi antara lain yaitu data rekam medis pasien yang tidak lengkap, mendapatkan terapi obat metoklopramid, dan mempunyai riwayat ekstrapiramidal sebelum penggunaan antipsikotik.

Prevalensi pasien skizofrenia dengan terapi antipsikotik yang mengalami kejadian EPS adalah sebesar 72,2\%. Dari data tersebut maka perhitungan sample size untuk desain penelitian cross-sectional dilakukan dengan rumus:

$$
\mathrm{n}=\frac{\mathrm{Z}^{2} \mathrm{P}(1-\mathrm{P})}{\mathrm{d}^{2}}
$$

dengan

$\mathrm{Z}=$ tingkat kepercayaan;

$\mathrm{P}=$ prevalensi yang diharapkan (berdasarkan studi yang sama);

$\mathrm{d}=$ presisi.

Berdasarkan rumus di atas, dengan tingkat kepercayaan $90 \%$ dan presisi sebesar $10 \%$ diperoleh jumlah sampel yang harus diteliti sebanyak 77,4 pasien. Pada penelitian ini, sampel yang diambil sebanyak 100 pasien sehingga memenuhi jumlah sampel minimal. ${ }^{17}$

\section{Prosedur penelitian}

Sampel penelitian diseleksi dengan metode purposive sampling dengan jumlah sampel yang memenuhi kriteria yaitu sebanyak 100 pasien. Data yang dikumpulkan dari rekam medik berupa data karakteristik pasien (jenis kelamin, usia, tipe skizofrenia, status marital, pendidikan, pekerjaan, metode pembayaran (asuransi), penggunaan antipsikotik, terapi tambahan, keadaan pasien yang memiliki gejala ekstrapiramidal yaitu dengan melihat adanya diagnosis EPS terjadi setelah terapi antipsikoik dan pasien tidak ada riwayat EPS sebelumnya. Pengumpulan data dilakukan dengan menggunakan lembar pengumpul data (LPD).

\section{Analisis data}

Data yang diperoleh dianalisis menggunakan SPSS versi 16.0. Analisis univariat dilakukan untuk mengetahui gambaran dari karakterisik pasien serta penggunaan antipsikotik yang disajikan dalam bentuk tabel frekuensi dan persentase. Analisis bivariat menggunakan Chi-Square test dilakukan untuk mengetahui ada atau tidaknya hubungan antara pemberian antipsikotik terhadap kejadian efek samping EPS pada pasien skizofrenia rawat jalan di 
Rumah Sakit X wilayah Bantul, Yogyakarta. Variabel yang dimasukkan dalam tabel uji Chi-Square adalah terapi antipsikotik tunggal dan antipsikotik kombinasi sebagai variabel bebas (exposure) serta ada atau tidaknya kejadian efek samping EPS sebagai variabel terikat (outcome). Jika hasil analisis ChiSquare test diperoleh nilai $\mathrm{p}<0,05$, artinya terdapat hubungan yang bermakna.

\section{Hasil}

Pada penelitian ini, jumlah rekam medik pasien skizofrenia yang menjalani rawat jalan di Rumah Sakit X wilayah Bantul, Yogyakarta periode Januari hingga Desember 2017 yang memenuhi kriteria inklusi adalah sebanyak 100 pasien.

\section{Karakteristik pasien}

Karakteristik pasien skizofrenia rawat jalan di Rumah Sakit X wilayah Bantul, Yogyakarta meliputi jenis kelamin, usia, pendidikan, status marital, pekerjaan, dan status pembayaran pasien. Data karakteristik pasien dapat dilihat pada Tabel 1.

Pasien skizofrenia yang menjalani rawat jalan di Rumah Sakit X di wilayah Bantul Yogyakarta, baik berjenis kelamin laki-laki atau perempuan, tidak memiliki perbedaan yang cukup jauh, tetapi pasien laki-laki memiliki jumlah yang lebih banyak yaitu 52 pasien (52\%) dibandingkan dengan jumlah pasien perempuan yaitu 48 pasien (48\%). Distribusi usia paling banyak pada usia produktif 26-35 tahun yakni sebesar 32\%. Ditinjau dari tipenya, skizofrenia yang dialami oleh pasien paling banyak yaitu tipe skizofrenia paranoid (F 20.0) dengan jumlah sebanyak 75 pasien $(75 \%)$. Distribusi berdasarkan status pendidikan terbanyak adalah pada kelompok tamat SMA sebesar 33\%. Status marital pasien sebagian besar adalah belum/tidak menikah sebanyak $69 \%$. Sebagian besar pasien tidak bekerja (54\%). Asuransi kesehatan yang terbanyak digunakan adalah BPJS (69\%).

Pola penggunaan antipsikotik

Antipsikotik kombinasi lebih banyak digunakan dibandingkan dengan antipsikotik tunggal, yakni sejumlah (56\%) antisikotik kombinasi dan 44\% antipsikotik tunggal. Pada Tabel 2, dapat dilihat bahwa pasien yang mengalami sindrom ekstrapiramidal pada pemberian antipsikotik tunggal sebesar $11,4 \%$ dan pada antipsikotik kombinasi sebesar 12,5\%.

Selain dilihat dari jumlahnya, dapat dilihat pola penggunaan antipsikotik berdasarkan golongan obatnya seperti yang terlihat pada Tabel 3. Antipsikotik yang paling banyak digunakan berdasarkan penggolongan untuk jenis antipsikotik tunggal yaitu atipikal (27\%), sedangkan untuk jenis kombinasi yaitu tipikal-atipikal (41\%). Risperidon merupakan antipsikotik yang paling banyak digunakan, yang diikuti oleh kombinasi risperidon dan klozapin, kombinasi haloperidol dan klozapin, kombinasi risperidon dan klorpromazin, serta haloperidol secara berturut-turut sebesar $27 \%$, $17 \%, 10 \%, 7 \%$, serta $6 \%$.

Hubungan pemberian antipsikotik terhadap timbulnya EPS

Jenis antipsikotik yang terbanyak digunakan pada pasien skizofrenia rawat jalan di Rumah Sakit X wilayah Bantul adalah antipsikotik kombinasi yakni sebanyak 56 pasien (56\%) dengan sebanyak 7 pasien mengalami EPS, sedangkan untuk terapi antipsikotik tunggal sebanyak 44 pasien (44\%) dengan 5 pasien mengalami EPS.

Analisis uji Chi-Square digunakan untuk melihat apakah terdapat hubungan antara pemberian antipsikotik terhadap timbulnya EPS, dengan variabel yang dimasukkan yaitu terapi antipsikotik tunggal dan antipsikotik kombinasi, antipiskotik tunggal yang terdiri dari golongan tipikal dan atipikal, kemudian antipiskotik kombinasi yang terdiri dari atipikal-atipikal, tipikal-tipikal, dan tipikal- 
atipikal terhadap kejadian efek samping EPS. Hasil dari analisis uji Chi-Square seperti yang ditunjukkan pada Tabel 4 menunjukkan nilai $p=1,000(p>0,05)$ yang artinya tidak terdapat hubungan antara pemberian antipsikotik, baik antipsikotik tunggal atau kombinasi, terhadap timbulnya efek samping EPS pada pasien skizofrenia yang menjalani rawat jalan Rumah
Sakit X wilayah Bantul, Yogyakarta.

Hasil analisis uji Chi-Square pengaruh antipsikotik tunggal terhadap kejadian EPS pada pasien skizofrenia dapat dilihat pada Tabel 4, sedangkan untuk pengaruh pemberian antipsikotik kombinasi, dilakukan alternatif penggabungan se $^{18}$ sehingga diperoleh hasil seperti pada Tabel 5 .

Tabel 1 Karakteristik Subjek Penelitian

\begin{tabular}{|c|c|c|}
\hline \multirow{2}{*}{ Karakteristik Demografi } & \multicolumn{2}{|c|}{$\mathrm{N}=\mathbf{1 0 0}$} \\
\hline & Jumlah Pasien & Persentase \\
\hline \multicolumn{3}{|l|}{ Jenis Kelamin } \\
\hline Perempuan & 52 & 52 \\
\hline Laki-laki & 48 & 48 \\
\hline \multicolumn{3}{|l|}{ Usia } \\
\hline Remaja akhir (17-25 tahun) & 14 & 14 \\
\hline Dewasa awal (26-35 tahun) & 32 & 32 \\
\hline Dewasa akhir (36-45 tahun) & 26 & 26 \\
\hline Lansia awal (46-55 tahun) & 19 & 19 \\
\hline Lansia akhir (56-65 tahun) & 8 & 8 \\
\hline Manula ( $>65$ tahun) & 1 & 1 \\
\hline \multicolumn{3}{|l|}{ Tipe Skizofrenia } \\
\hline F 20.0 (Skizofrenia paranoid) & 75 & 75 \\
\hline F 20.1 (Skizofrenia hebrefenik) & 2 & 2 \\
\hline F 20.3 (Skizofrenia tak terinci) & 19 & 19 \\
\hline F 20.5 (Skizofrenia Residual) & 4 & 4 \\
\hline \multicolumn{3}{|l|}{ Pendidikan } \\
\hline Tidak sekolah & 20 & 20 \\
\hline SD & 17 & 17 \\
\hline SMP & 20 & 20 \\
\hline SMA & 33 & 33 \\
\hline D1/D2/D3 & 1 & 1 \\
\hline Sarjana & 9 & 9 \\
\hline \multicolumn{3}{|l|}{ Status } \\
\hline Tidak/belum menikah & 69 & 69 \\
\hline Menikah & 28 & 28 \\
\hline Duda/janda & 3 & 3 \\
\hline \multicolumn{3}{|l|}{ Pekerjaan } \\
\hline Karyawan swasta & 17 & 17 \\
\hline PNS & 2 & 2 \\
\hline Wiraswasta & 1 & 1 \\
\hline Petani/buruh & 14 & 14 \\
\hline Lain-lain & 12 & 12 \\
\hline Tidak bekerja & 54 & 54 \\
\hline \multicolumn{3}{|l|}{ Pembayaran } \\
\hline Umum & 16 & 16 \\
\hline BPJS & 69 & 69 \\
\hline KIS & 14 & 14 \\
\hline Lain-lain & 1 & 1 \\
\hline
\end{tabular}


Tabel 2 Penggunaan Antipsikotik Tunggal dan Kombinasi

\begin{tabular}{lccc}
\hline \multirow{2}{*}{ Obat } & \multirow{2}{*}{ Frekuensi } & Ya & Tidak \\
\cline { 3 - 4 } & & $5(11,4 \%)$ & $39(88,6 \%)$ \\
\hline Tunggal & 44 & $7(12,5 \%)$ & $49(87,5 \%)$ \\
Kombinasi & 56 & \multicolumn{2}{c}{ Sindrom Ekstrapiramidal } \\
\hline
\end{tabular}

\section{Pembahasan}

Pasien skizofrenia di Rumah Sakit X di wilayah Bantul, Yogyakarta, didominasi oleh laki-laki yakni sebanyak $52 \%$ dan perempuan 48\%. Hasil ini sejalan dengan hasil penelitian yang dilakukan oleh Perwitasari et al. (2008) bahwa pasien skizofrenia di Rumah Sakit Ghrasia Yogyakara didominasi oleh laki-laki sejumlah 53 pasien dan perempuan sejumlah 47 pasien. Hal ini disebabkan wanita memiliki hormon estrogen yang dapat menghambat pelepasan dan mencegah terjadi peningkatan dopamin, sehingga skizofrenia tidak terjadi. ${ }^{19}$

Tabel 3 Penggunaan Antipsikotik berdasarkan Golongan

\begin{tabular}{|c|c|c|c|c|}
\hline \multirow{2}{*}{ Tipe Antipsikotik } & \multirow{2}{*}{ Golongan Antipsikotik } & \multirow{2}{*}{ Frekuensi } & \multicolumn{2}{|c|}{$\begin{array}{c}\text { Sindrom } \\
\text { Ekstrapiramidal }\end{array}$} \\
\hline & & & Ya & Tidak \\
\hline Haloperidol & Tipikal & 6 & 1 & 5 \\
\hline Lodomer & Tipikal & 3 & - & 3 \\
\hline Injeksi Sikzonoate & Tipikal & 4 & 1 & 3 \\
\hline Klozapin & Atipikal & 1 & - & 1 \\
\hline Risperidone & Atipikal & 27 & 2 & 25 \\
\hline Olanzapin & Atipikal & 1 & 1 & - \\
\hline Seroquel & Atipikal & 2 & - & 2 \\
\hline Risperidon-Klozapin & Atipikal-Atipikal & 17 & 1 & 16 \\
\hline Seroquel-Klozapin & Atipikal-Atipikal & 1 & - & 1 \\
\hline Risperidon-Klorpromazin & Tipikal-Atipikal & 7 & - & 7 \\
\hline Haloperidol-Klozapin & Tipikal-Atipikal & 10 & 3 & 7 \\
\hline Haloperidol-Risperidon & Tipikal-Atipikal & 1 & - & 1 \\
\hline Haloperidol-Seroquel & Tipikal-Atipikal & 2 & 1 & 1 \\
\hline Lodomer-Klozapin & Tipikal-Atipikal & 1 & - & 1 \\
\hline Stelosi-Klozapin & Tipikal-Atipikal & 1 & - & 1 \\
\hline Injeksi Siksonoat-Klozapin & Tipikal-Atipikal & 1 & 1 & - \\
\hline Haloperidol-Klorpromazin & Tipikal-Tipikal & 4 & 1 & 3 \\
\hline Haloperidol-Stelosi & Tipikal-Tipikal & 1 & - & 1 \\
\hline Risperidon-Aripripazol-Klorpromazin & Atipikal-Atipikal-Tipikal & 1 & - & 1 \\
\hline Haloperidol-Klorpromazin-Injeksi Sikzonoat & Tipikal-Tipikal-Tipikal & 2 & - & 2 \\
\hline Haloperidol-Klorpromazin-Risperidon & Tipikal-Tipikal-Atipikal & 1 & - & 1 \\
\hline Haloperidol-Risperidon-Klozapin & Tipikal-Atipikal-Atipikal & 3 & - & 3 \\
\hline Risperidon-Stelosi-Klorpromazin & Atipikal-Tipikal-Tipikal & 1 & - & 1 \\
\hline Stelosi-Haloperidol-Klozapin & Tipikal-Tipikal-Atipikal & 1 & - & 1 \\
\hline Injeksi Siksonoat-Haloperidol-Klozapin & Tipikal-Tipikal-Atipikal & 1 & - & 1 \\
\hline
\end{tabular}


Tabel 4 Analisis Uji Chi-Square Antipsikotik Tunggal dan Kombinasi

\begin{tabular}{|c|c|c|c|c|c|}
\hline \multirow{3}{*}{ Jenis Antipsikotik } & \multicolumn{4}{|c|}{ Sindrom Ekstrapiramidal } & \multirow{3}{*}{ Nilai $p$} \\
\hline & \multicolumn{2}{|c|}{ Ya } & \multicolumn{2}{|c|}{ Tidak } & \\
\hline & $\mathbf{N}$ & $\%$ & $\mathbf{N}$ & $\%$ & \\
\hline Tunggal & 5 & 11,4 & 39 & 88,6 & \multirow{3}{*}{1} \\
\hline Kombinasi & 7 & 12,5 & 49 & 87,5 & \\
\hline Total & 12 & 12,0 & 88 & $\mathbf{8 8 , 0}$ & \\
\hline \multicolumn{6}{|c|}{ Tabel 5 Analisis Uji Chi-Square Antipsikotik Tunggal } \\
\hline \multirow{3}{*}{ Jenis Antipsikotik } & \multicolumn{4}{|c|}{ Sindrom Ekstrapiramidal } & \multirow{3}{*}{ Nilai $p$} \\
\hline & \multicolumn{2}{|c|}{ Ya } & \multicolumn{2}{|c|}{ Tidak } & \\
\hline & $\mathbf{N}$ & $\%$ & $\mathbf{N}$ & $\%$ & \\
\hline Tipikal & 2 & 40,0 & 11 & 28,2 & \multirow{3}{*}{0,4697} \\
\hline Atipikal & 3 & 60,0 & 28 & 71,8 & \\
\hline Total & 5 & 100,0 & 39 & 100,0 & \\
\hline
\end{tabular}

Prevalensi skizofrenia secara teori memiliki perbandingan yang sama antara pasien lakilaki dan perempuan. Puncak onset skizofrenia lebih lambat pada wanita, yaitu terjadi usia 25-35 tahun dan pada lelaki pada usia 15-25 tahun. ${ }^{20}$

Distribusi usia pada penelitian ini dibagi menjadi 6 kelompok usia yang berdasar atas panduan Riskesdas tahun 2013, yaitu usia remaja akhir (17-25 tahun), dewasa awal (26-35 tahun), dewasa akhir (36-45 tahun), lansia awal (46-55 tahun), lansia akhir (5665 tahun), dan manula ( $>65$ tahun). Pasien skizofrenia yang menjalani rawat jalan di Rumah Sakit X wilayah Bantul Yogyakarta paling banyak berusia 26-35 tahun atau masuk ke usia dewasa awal dengan jumlah sebanyak 32 pasien $(32 \%)$. Hal ini disebabkan pada usia tersebut terdapat banyak faktor yang dapat memicu penyakit skizofrenia, salah satunya stres akibat beban tanggung jawab pekerjaan yang besar. Hasil penelitian ini sesuai dengan teori dari sebuah penelitian yang menyatakan bahwa sebanyak $90 \%$ pasien yang memiliki diagnosis skizofrenia terjadi di rentang usia 15-55 tahun. ${ }^{21}$

Skizofrenia umumnya mulai muncul pada saat usia remaja atau belum menikah. Pasien dengan gangguan jiwa skizofrenia ini akan mengalami masa pengobatan dalam jangka

Tabel 6 Analisis Uji Chi-Square Antipsikotik Kombinasi dan Gabungan Kombinasi

\begin{tabular}{|c|c|c|c|c|c|}
\hline \multirow{3}{*}{ Jenis Antipsikotik } & \multicolumn{4}{|c|}{ Sindrom Ekstrapiramidal } & \multirow{3}{*}{ Nilai $p$} \\
\hline & \multicolumn{2}{|c|}{$\mathbf{Y a}$} & \multicolumn{2}{|c|}{ Tidak } & \\
\hline & $\mathbf{N}$ & $\%$ & $\mathbf{N}$ & $\%$ & \\
\hline \multicolumn{6}{|l|}{ Kombinasi } \\
\hline Atipikal-Atipikal & 1 & 14,3 & 17 & 34,7 & \\
\hline Tipikal-Tipikal & 1 & 14,3 & 6 & 12,2 & \\
\hline Tipikal-Atipikal & 5 & 71,4 & 26 & 53,1 & \\
\hline Total & 7 & 100,0 & 49 & 100,0 & \\
\hline \multicolumn{6}{|l|}{ Gabungan Kombinasi } \\
\hline Atipikal-Atipikal & 1 & 14,3 & 17 & 34,7 & 0,269 \\
\hline Tipikal-Tipikal + Tipikal-Atipikal & 6 & 85,7 & 32 & 65,3 & \\
\hline Total & 7 & 100,0 & 49 & 100,0 & \\
\hline
\end{tabular}


panjang, sehingga sulit untuk membangun relasi, dan relationship (contohnya menikah) akan menjadi sedikit terganggu. ${ }^{22,23} \mathrm{Hal}$ ini sejalan dengan hasil penelitian ini bahwa status marital pasien didominasi kelompok belum/tidak menikah sebesar $69 \%$. Dilihat dari tipe skizofrenia, tipe paranoid (F 20.0) merupakan tipe yang paling banyak diderita oleh pasien skizofrenia yang menjalani rawat jalan di Rumah Sakit X di wilayah Bantul Yogyakarta yakni sebanyak 75 pasien (75\%), diikuti dengan tipe skizofrenia tak terinci sejumlah 19 pasien (19\%).

Kelompok pendidikan dalam penelitian kali ini dibagi ke dalam 6 kelompok, yaitu pasien dengan pendidikan tamat SD, SMP, SMA, diploma, sarjana, dan tidak bersekolah. Berdasarkan hasil penelitian ini, kelompok terbanyak dari pasien skizofrenia rawat jalan di Rumah Sakit X di wilayah Bantul pada periode Januari-Desember 2017 dilihat dari pendidikan terakhirnya adalah pada tingkat SMA. Seseorang dengan penyakit skizofrenia cenderung mempunyai jaringan otak yang relatif lebih sedikit bila dibandingkan dengan orang pada umumnya, sehingga hal tersebut akan memengaruhi tingkat pendidikan pasien, yang dalam hal ini hanya memiliki tingkat pendidikan SMA. ${ }^{24}$

Pola penggunaan terapi antipsikotik yang paling banyak digunakan adalah antipsikotik kombinasi dengan jumlah sebesar 56 pasien (56\%), sedangkan untuk antipsikotik tunggal sebanyak 44 pasien (44\%). Pada penelitian lain yang dilakukan oleh Purwandityo et al. (2018) pada pasien skizofrenia rawat inap di RSJ Prof. Soerojo Magelang, penggunaan antipsikotik kombinasi dari risperidon dan klozapin adalah yang terbanyak yakni sebesar 20,62\%, diikuti haloperidol dan klozapin sebesar $13,4 \%$ dan risperidon tunggal sebesar $12,37 \%$. Penggunaan polifarmasi antipsikosis atipikal di negara Asia rata-rata yaitu 42,2\% $\pm 12,0 \%$, dengan rincian antipsikotik yang paling sering digunakan berturut-turut adalah risperidon (36,9\%), olanzapin $(20,5 \%)$, dan klozapin $(18,5 \%) .{ }^{25}$ Berbeda dengan profil penggunaan antipsikotik di instalasi rawat inap jiwa RSD Madani Provinsi Sulawesi Tengah tahun 2014 yang hanya menggunakan antipsikotik tunggal dengan persentase paling besar yaitu penggunaan antipsikotik tipikal sejumlah $78 \%$ dan didominasi penggunaan haloperidol sebesar 43,3\% ${ }^{26}$

Penggunaan kombinasi antipsikotik dapat menghasilkan target reseptor yang bervariasi dan lebih besar. Sebagai akibatnya, penggunaan kombinasi ini dapat meningkatkan khasiat dari antipsikotik yakni dengan meningkatkan antagonis reseptor D2 dopaminergik secara aditif dan diharapkan dapat mengurangi efek samping yang terkait dengan dosis masingmasing obat. ${ }^{27}$

Pada penelitian ini, efek samping EPS akibat pemberian antipsikotik terjadi pada 12 pasien, sedangkan sebanyak 88 pasien lainnya tidak mengalami EPS. Antipsikotik tipikal mempunyai efek ekstrapiramidal lebih besar dibandingkan antipsikotik atipikal, namun pada penelitian ini tidak terlihat perbedaan efek tersebut. Pada pasien yang mendapatkan antipsikotik tipikal baik tunggal maupun kombinasi, terdapat 8 orang yang mengalami EPS, sedangkan pasien yang mendapatkan antipsikotik atipikal baik tunggal maupun kombinasi, terdapat 9 orang yang mengalami EPS.

Haloperidol merupakan obat antipsikotik yang termasuk dalam antipsikotik golongan tipikal kelas butirofenon, sedangkan antipsikotik klorpromasin termasuk dalam kelas fenotiazin. Perbedaan dari kedua antipsikotik ini terletak pada afinitasnya dalam mengikat reseptor dopamin D2. Obat antipsikotik haloperidol diketahui memiliki afinitas 50 kali lebih kuat atau 90\% kekuatan jika dibandingkan dengan obat antipsikotik klorpromasin yang hanya $70 \%$ kekuatannya dalam mengikat reseptor dopamin 2 di striatum, sehingga hal tersebut menjadi alasan antagonis reseptor dopamin 
D2 tidak hanya dalam efek antipsikotik, tetapi juga dalam menyebabkan EPS. Antipsikotik generasi kedua, atau biasa disebut sebagai antipsikotik atipikal, memiliki afinitas yang lebih besar pada reseptor dopamin 4, histamin, serotonin, muskarinik dan afla adrenergik. Namun, pada umumnya antipsikotik atipikal memiliki afinitas yang kecil terhadap reseptor dopamin 2 sehingga memiliki efek samping EPS yang lebih kecil. Antipsikotik generasi kedua diduga efektif untuk mengatasi gejala positif maupun gejala negatif, sedangkan generasi pertama umumnya hanya merespon untuk gejala positif. Akan tetapi, antipsikotik generasi kedua ini mempunyai efek samping gangguan kardiovaskular, penambahan berat badan, dan diabetes melitus. ${ }^{28}$

Efek samping EPS tidak hanya diakibatkan penggunaan terapi antipsikotik saja. Terdapat beberapa obat lain yang dapat menyebabkan EPS, salah satunya adalah metoklopramid. Metoklopramid merupakan obat antiemetik dan gastrokinetik untuk mengobati mual, muntah, gerd, gastroparesis, dan migrain. Meskipun obat metoklopramid memiliki efek yang signifikan dalam mengobati mual dan muntah, serta merupakan obat agonis reseptor dopamin dan gen antiemetik yang paling terkenal, tetapi penggunaannya telah dibatasi oleh European Medicines Agency (EMA) karena dapat menyebabkan efek samping neurologis akut dan kronis. ${ }^{29}$ Efek samping neurologis yang sering muncul akibat dari penggunaan obat metoklopramid adalah EPS dengan gejala di antaranya parkinsonisme, distonia akut, akathisia dan bahkan bisa menjadi diskinesia tardiv jika tidak terobati dengan benar. ${ }^{30}$ Diskinesia tardiv merupakan suatu sindrom yang ditandai oleh gerakan berulang pada bibir, lidah, dan wajah yang persisten dan berpotensi ireversibel. ${ }^{31}$ Oleh sebab itu, pasien skizofrenia yang menggunakan terapi obat metoklopramid harus dieksklusi sebab dapat menjadi bias dalam hasil penelitian.

Penggunaan antipsikotik menimbulkan efek samping EPS jika dosis yang diberikan terlalu besar. Namun, munculnya EPS tidak hanya berasal dari penggunaan antipiskotik saja. Terdapat dua faktor lainnya yang dapat memicu timbulnya EPS yaitu kelainan genetik pasien dan konsumsi metoklopramid dalam kurun waktu yang sangat lama. ${ }^{2}$ Data tabel uji Chi-Square menunjukkan nilai $\mathrm{p}=1,000$ $(\mathrm{p}>0,05)$, artinya tidak terdapat hubungan antara pemberian antipsikotik baik tunggal maupun kombinasi terhadap timbulnya efek samping EPS pada pasien skizofrenia yang menjalani rawat jalan di Rumah Sakit X di wilayah Bantul. Hal tersebut terjadi karena dari total 100 orang pasien pada penelitian ini, hanya terdapat 12 pasien yang mengalami efek samping EPS. Terjadinya EPS pada penelitian ini berdasar pada diagnosis dokter yang tercatat dalam rekam medik dan bukan berdasarkan pengamatan pada pasien secara langsung, sehingga menurut hasil uji analisis di atas, pemberian terapi antipsikotik pada pasien skizofrenia baik terapi tunggal atau kombinasi tidak memberikan pengaruh yang besar dalam menginduksi terjadinya EPS pada pasien skizofrenia yang menjalani rawat jalan di Rumah Sakit X wilayah Bantul Yogyakarta periode Januari-Desember 2017.

Selain dilihat hubungan antara terapi tunggal dan kombinasi terhadap efek samping EPS, pada penelitian ini juga dikaji hubungan antara golongan antipiskotik baik itu tunggal tipikal dan tunggal atipikal maupun kombinasi atipikal-atipikal, tipikal-tipikal, serta tipikalatipikal terhadap efek samping EPS pada pasien skizofrenia. Hasil dari analisis uji $\mathrm{Chi}$ Square memberikan nilai $\mathrm{p}=0,467(\mathrm{p}>0,05)$, yang artinya tidak terdapat hubungan antara pemberian terapi tunggal antipsikotik baik itu tipikal maupun atipikal terhadap kejadian efek samping EPS pada pasien skizofrenia.

Uji yang digunakan untuk menganalisis antipsikotik kombinasi (baik atipikal-atipikal, tipikal-tipikal, atau tipikal-atipikal) terhadap kejadian efek samping EPS adalah uji Chi- 
Square, tetapi dalam hasil analisis diperoleh terdapat 3 sel yang mempuyai nilai expected kurang dari 5, sehingga uji ini tidak dapat diterima. Alternatif yang dapat digunakan dalam uji ini yakni melalui penggabungan sel $^{18}$ antara terapi antipsikotik tipikal-tipikal dengan tipikal-atipikal menjadi satu kategori, sehingga dapat diketahui apakah antipsikotik tipikal ini benar-benar dapat menyebabkan efek samping EPS pada pasien skizofrenia sesuai yang telah disebutkan dalam beberapa literatur, serta mengingat bahwa pasien yang menggunakan terapi antipsikotik kombinasi tipikal-tipikal, tipikal-atipikal lebih banyak dari pada pasien yang menggunakan terapi antipsikotik atipikal-atipikal pada penelitian ini. Namun demikian, hal tersebut nyatanya tidak terbukti secara statistik pada penelitian ini, sebab hasil yang diperoleh dari analisis uji Chi-Square setelah proses penggabungan adalah $p=0,269(p>0,05)$ yang artinya tidak terdapat hubungan antara pemberian terapi antipsikotik kombinasi, baik atipikal-atipikal maupun tipikal-tipikal atau tipikal-atipikal, terhadap kejadian efek samping EPS pada pasien skizofrenia yang menjalani rawat jalan di Rumah Sakit X wilayah Bantul, Yogyakarta.

Keterbatasan pada penelitian ini adalah pengambilan data dilakukan secara retrospekif berdasarkan catatan rekam medik, sehingga peneliti tidak melakukan pengamatan secara langsung pada pasien yang mendapatkan terapi antipsikotik terhadap kejadian EPS. Kejadian eksrtrapiramidal diketahui berdasarkan data rekam medik diagnosis EPS yang diperoleh setelah mendapatkan antipsikotik.

\section{Simpulan}

Penggunaan terapi antipiskotik pada pasien skizofrenia yang menjalani rawat jalan di Rumah Sakit X wilayah Bantul, Yogyakarta pada periode Januari-Desember 2017, baik terapi tunggal maupun terapi kombinasi, tidak memiliki hubungan terhadap timbulnya efek samping sindrom ekstrapiramidal $(\mathrm{p}=1,000)$. Penggunaan terapi antipsikotik tunggal baik itu tipikal maupun atipikal tidak memiliki hubungan terhadap timbulnya efek samping sindrom ekstrapiramidal $(\mathrm{p}=0,467)$, begitu pula dengan penggunaan terapi antipsikotik kombinasi, baik kombinasi atipikal-atipikal, tipikal-tipikal maupun tipikal-atipikal, tidak memiliki hubungan terhadap timbulnya efek samping sindrom ekstrapiramidal $(\mathrm{p}=0,269)$.

\section{Ucapan Terima Kasih}

Penulis mengucapkan terima kasih kepada seluruh pihak yang berkontribusi di dalam penelitian ini, antara lain bagian rekam medik, dokter, perawat dan tenaga kesehatan lain di Rumah Sakit X wilayah Bantul Yogyakarta atas bantuan dan arahan yang diberikan.

\section{Pendanaan}

Penelitian ini memperoleh dana hibah internal Universitas Ahmad Dahlan tahun 2017.

\section{Konflik Kepentingan}

Seluruh penulis menyatakan tidak terdapat potensi konflik kepentingan dengan penelitian, kepenulisan (authorship), dan atau publikasi artikel ini.

\section{Daftar Pustaka}

1. Badan Penelitian dan Pengembangan Kesehatan Kementerian Kesehatan Republik Indonesia. Riskesdas dalam angka Provinsi DIY tahun 2013, Igarss 2014. Jakarta: Kementerian Kesehatan Republik Indonesia; 2014.

2. Syarif A, Estuningtyas A, Setiawati A, Muchtar A, Arif A, Bahry B. Farmakologi dan terapi Jakarta: Balai Penerbit FKUI; 2012.

3. Perhimpunan Dokter Spesialis Kedokteran 
Jiwa Indonesia. Konsensus penatalaksanaan gangguan skizofrenia, Indonesia; 2011.

4. Jesić MP, Jesić A, Filipović JB, Zivanović O. Extrapyramidal syndromes caused by antipsychotics. Med Pregl. 2012;65(1112):521-6. doi: 10.2298/MPNS1212521P

5. Patel KR, Cherian J, Gohil K, Atkinson D. Schizophrenia: Overview and treatment options. Pharm Ther. 2014;39(9):638-45.

6. Wijono R, Nasrun MW, Damping CE. Gambaran dan karakteristik penggunaan triheksifenidil pada pasien yang mendapat terapi antipsikotik. J Indon Med Assoc. 2013;63(1):14-20

7. Harvey PD, Rosenthal JB. Treatment resistant schizophrenia: Course of brain structure and function. Prog Neuropsychopharmacol Biol Psychiatry. 2016;70:111-6. doi: 10.1016/j.pnpbp.201 6.02.008

8. Peluso MJ, Lewis SW, Barnes TR, Jones PB. Extrapyramidal motor side-effects of first- and second-generation antipsychotic drugs. Br J Psychiatry. 2012;200(5):38792. doi: 10.1192/bjp.bp.111.101485..

9. Zhang Y, Liu Y, Su Y, You Y, Ma Y, Yang $\mathrm{G}$, et al. The metabolic side effects of 12 antipsychotic drugs used for the treatment of schizophrenia on glucose: A network meta-analysis. BMC Psychiatry. 2017;17 (1):373. doi: 10.1186/s12888-017-15390.

10. Riordan HJ, Antonini P, Murphy MF. Atypical antipsychotics and metabolic syndrome in patients with schizophrenia: Risk factors, monitoring, and healthcare implications. Am Health Drug Benefits. 2011;4(5):292-302.

11. Agid O, Schulze L, Arenovich T, Sajeev G, McDonald K, Foussias G, et al. Antipsychotic response in first-episode schizophrenia: Efficacy of high doses and switching. Eur Neuropsychopharmacol. 2013;23(9):1017-22. doi: 10.1016/j.euro neuro.2013.04.010

12. Marvanova M. Strategies for prevention and management of second generation antipsychotic-induced metabolic side effects. Ment Health Clinician. 2013;3(3): 154-61. doi: 10.9740/mhc.n166832

13. Su J, Barr AM, Procyshyn RM. Adverse events associated with switching antipsychotics. J Psychiatry Neurosci. 2012;37(1):E1-E2. doi: 10.1503/jpn. 110 096

14. de Smidt C, Haffmans J, Hoencamp E. Antipsychotics switching strategies in real life: A longitudinal study in clinical practice. Eur J Psychiat. 2012;26(1):41 -9. doi: 10.4321/S0213-61632012000100004

15. Cerovecki A, Musil R, Klimke A, Seemüller F, Haen E, Schennach R, et al. Withdrawal symptoms and rebound syndromes associated with switching and discontinuing atypical antipsychotics: theoretical background and practical recommendations. CNS Drugs. 2013;27 (7):545-72. doi: 10.1007/s40263-013007 9-5.

16. Jarut YM, Fartimawali, Wiyono WI, Tinjauan penggunaan antipsikotik pada pengobatan skizofrenia di RS Prof. Dr. V. L. Ratumbuysang Manado periode Januari-Maret 2013. Pharmacon. 2013;2 (3):54-7.

17. Pourhoseingholi MA, Vahedi M, Rahimzadeh M. Sample size calculation in medical studies. Gastroenterol Hepatol Bed Bench 2013;6(1):14-7. doi: 10.22037 /ghfbb.v6i1.332

18. Dahlan MS. Statistik untuk kedokteran dan kesehatan deskriptif, bivariat, dan multivariat dilengkapi aplikasi menggunakan SPSS. Jakarta: Salemba Medika; 2011.

19. Tardy M, Huhn M, Kissling W, Engel RR, Leucht S. Haloperidol versus low-potency first-generation antipsychotic drugs for schizophrenia. Cochrane Database Syst Rev. 2014;(7):CD009268. doi: 10.1002/1 4651858.CD009268.pub2.

20. Sadock BJ, Sadock VA. Kaplan and 
Sadock's comprehensive textbook of psychiatry, $7^{\text {th }}$ ed. Philadelphia: Lippincott, Williams and Wilkins; 2003.

21. Kaplan HI, Sadock BJ, Grebb JA. Sinopsis psikiatri, edisi ke-7, jilid 1. Jakarta: Binarupa Aksara; 2001.

22. Tomb DA. Buku saku psikiatri. Jakarta: EGC; 2004.

23. Sira I. Karakteristik skizofrenia di Rumah Sakit Khusus Alianyang Pontianak periode 1 Januari-31 Desember 2009. J Mahasiswa PSPD FK Univ Tanjungpura. 2013;2(1):117.

24. Videbeck SL. Buku ajar keperawatan jiwa, edisi pertama. Jakarta: EGC; 2008.

25. Purwandityo AG, Febrianti Y, Sari CP, Ningrum VDA, Sugiyarto OP. Pengaruh antipiskotik terhadap penurunan skor the positive and negative syndrome scaleexcited component. Indones J Clin Pharm. 2018;7(1):19-29. doi: 10.15416/ijcp.201 8.7.1.19

26. Fahrul, Mukaddas A, Ingrid F. Rasionalitas penggunaan antipsikotik pada pasien skizofrenia di instalasi rawat inap jiwa RSD Madani Provinsi Sulawesi Tengah periode Januari-April 2014. Online J Natural Sci. 2014;3(2):18-29. doi: 10.2012/
27. Handayani DS, Cahaya N, Srikartika VM. Pengaruh pemberian kombinasi antipsikotik terhadap efek samping sindrom ekstrapiramidal pada pasien skizofrenia di Rumah Sakit Jiwa Sambang Lihum. Farmaka. 2018;15(3):86-95.

28. Yulianty MD, Cahaya N, Srikartika VM. Studi penggunaan antipsikotik dan efek samping pada pasien di Rumah Sakit Jiwa Sambang Lihum Kalimantan Selatan. J Sains Farmasi Klinis. 2016;3(2):153-64. doi: 10.25077/jsfk.3.2.153-164.2017

29. Valkova M, Stamenov B, Peychinska D, Veleva I, Dimitrova P, Radeva P. Metoclopramide-induced extrapyramidal signs and symptoms-Brief review of literature and case report. J IMAB. 2014; 20(6):539-41. doi: 10.5272/jimab.20142 06.539

30. De Ronde MW, Kingma HJ, Munts AG. Severe parkinsonism due to metoclopramide: The importance of early recognition. Ned Tijdschr Geneeskd. 2013;157(26):A6037.

31. Rao AS, Camilleri M. Metoclopramide and tardive dyskinesia. Aliment Pharmacol Ther. 2010;31(1):11-9. doi: 10.1111/j.136 5-2036.2009.04189.x. 